\title{
2 自由度最適有限整定サーボ系の設計
}

\author{
学生員 原田賢一（広島工業大学）学生員 松岡孝司（広島工業大学） \\ 正 員 村田弘志 (広島工業大学)
}

A Design Method of Optimal Deadbeat Servo System with Two-Degree-of-Freedom.

Kenichi Harada, Takashi Matsuoka, Hiroshi Murata

(Hiroshima Institute of Technology)

\begin{abstract}
In this paper, we propose a new design method of optimal deadbeat servo system with two-degree-of-freedom. In this design method, the desired value tracking characteristics and disturbance rejection characteristics can be performed by different compensators.

The optimal deadbeat control signal which minimizes the quadratic performance index for control signal and deviation can be easily obtained from the matrix computation using sampled data of the step response of the system. Then, the deadbeat controller can be designed by using the control signal.

We show our simulation results with several numerical data to demonstrate the effectiveness of the present method.
\end{abstract}

キーワード：2 自由度最適有限整定制御，2自由度有限整定サーボ采，デッドビート制御

\section{1. まえがき}

ステップ状目標值に追従する 1 形サーボ系では，制御対 象のパラメータ変動や定值外乱に対応するため, 主ループ に穦分補償を行っており，制御対象が正確に把握され外乱 も存在しないならば，目標值追従特性は積分補償なしで害 現できる1〉。そこで，目標值追従特性と外乱抑制特性を 各々独立した補償器で寒現する 2 自由度サーボ系の設計法 が池田 $5^{2,3)}$ 藤㥓ら荻原ら ${ }^{5,6)}$ によって提案されている。ま たそのディジタル型 2 自由度 L Q I サーボ系の設計と実機 一の応用も文献6)で報告されている。

一方，過渡応答波形の改善や操作量制限一の対応が可能 な最適有限整定芯答サーボ系の設計については，主ループ 内の楥和フィルタと状態局部フィードバックを用いる西村 らクの方法や，制御对象に前置補償器を加え状態フィード バックにより局部補償老行う瓜合ら ${ }^{8)}$ の方法がよく知られ ている。また，2自由度デッドビート制御として出力

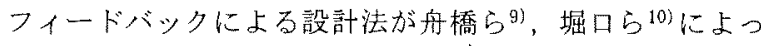
て報告されており，文献2～6）のように目標值追従特性と 外乱㧕制特性を分離した設計法ではないが操作量と偏差に 関する 2 次形式評洒関数を最小化するよう線形最適化手法 を用いて有限整定サーボ采を実現している。

筆者らも，同様な制御構成による最適有限整定制御系の 設計法について, 制御対象の次数を $n$ とするとき，乙のス テップ㐫答のサンプル值を用いた簡単な行列演算から制御 段数が $N=n+k(k \geq 1)$ なる最適有限整定操作量 $\boldsymbol{u}_{k}$ を求め, こ
の操作量に対する制御対象の有限整定応答を閉ループ系の 規範モデル応答とする最適有限整定サ一ボ采の設計法を提 案しているが11 14)目標值に注目して $N$ 段制御の最適有限 整定サーボ系を設計していることから，外乱に対しては必 ずしも最適でない $N$ 段の有限整定制御応答となっていた。

本論文は，目標入力に対する応答については積分補償の 効果が現れない上う積分器の出力端に制御対象からの状態 フィードバックによる $N$ 段の最適有限整定制御を実現し， 外乱に対しては $n$ 段の最短時間又は $N^{\prime}$ 段の最適有限整定応 答を得るよう積分補償を行う 2 自由度最適有限整定応答 サーボ系の設計法を提案したものである。制御系は文献6) で萩原らの用いたものを基本にして，制御対象に前置補償 器 $G_{c}(z)$ 上状態フィードバックループに $G_{a}(z)$ なる補償器 を追加したサーボ系の構成となっており，目標值と外乱に 対し独立した補償器の設計により2自由度最適有限整定制 御を害現している。前述の筆者らの手法による最適有限整 定操作量 $\boldsymbol{u}_{k}$ に対応する規範モデル応答を用いて目標値への 追従は $N$ 段の最適有限整定広答特性を，外乱については $n$ 段， $N^{\prime}$ 段の最短および最適有限整定外乱抑制特性をもたせ るように補償器を設計した。従来のように制御装置を設計 後に閉ループ系の応答を求めて試行を繰り返す必要がな く， $\boldsymbol{u}_{k}$ に対する規範モデル答が制御仕棣を満たすことを 確認すれば対応する制御装置が容易に求まり，設計手法も 簡単である。数值例により目標值および外乱のステップ変 化および制御対象のパラメータ変化に対するシミュレー ション結果を示し，提案した手法の有効性を示している。 


\section{2. 系の記述と問題の設定}

制御対象の伝達関数を $G(s)$ とし, 次数を $n$ ，ゲインを $K$ ，ステップ応答を $h(t)$ とする単一入出力系を考える。ま た, 入力を $u(t)$, 出力を $y(t)$ とし $G(s)$ の入力端にサンプ 儿周期が $\theta$ の零次ホールド回路を置き，例えば出力 $y(t)$ の場合サンプル值を $y_{i}=y(i \theta)$ と表示する。このとき，入出 力間には次式が成立している。

$$
y_{i}=\sum_{j=1}^{i} g_{j} u_{i-j} \quad(i=0,1, \cdots)
$$

ここに， $g_{i}$ は $g_{i}=h_{i}-h_{i-1}$ なるマルコフパラメータであり， $G(s)$ のパルス伝達関数を $G(z)$ とすれば,

$$
\begin{gathered}
G(z)=\frac{b(z)}{1+a(z)}=\sum_{i=1}^{\infty} g_{i} z^{-i} \\
\left(h_{i}=\sum_{j=1}^{i} g_{j}\right)
\end{gathered}
$$

と表される。ただし、

$$
\begin{aligned}
& a(z)=a_{1} z^{-1}+a_{2} z^{-2}+\cdots+a_{n} z^{-n} \\
& b(z)=b_{1} z^{-1}+b_{2} z^{-2}+\cdots+b_{n} z^{-n}
\end{aligned}
$$

である。このとき， $a_{i}, b_{i}(i=1 \sim n)$ と $g_{i}$ の間には次式の 関係が成立している。

$$
g_{i}= \begin{cases}b_{i}-\sum_{i=1}^{i-1} a_{l} g_{i-i} & \left(i=1 \sim n, g_{0}=0\right) \\ -\sum_{i=1}^{n} a_{l} g_{i-l} & (i \geq n+1)\end{cases}
$$

また，対応する状態方程式と出力方程式は可制御正準形 として次式のように得られる。

$$
\begin{aligned}
& \boldsymbol{x}_{i+1}=\Phi \boldsymbol{x}_{i}+\Gamma u_{i} \\
& y_{i}=\Psi \boldsymbol{x}_{i} \\
& \Phi=\left[\begin{array}{cccc}
0 & 1 & & 0 \\
\vdots & \ddots & \ddots & \\
0 & \cdots & 0 & 1 \\
-a_{n} & \cdots & -a_{2} & -a_{1}
\end{array}\right] \quad(n \times n) \\
& \Gamma=[0, \cdots, 0,1]^{T} \\
& \Psi=\left[b_{n}, \cdots, b_{2}, b_{1}\right]
\end{aligned}
$$

なお，1形サーボ系の構成条件として次式を仮定する。

$$
\operatorname{rank}\left[\begin{array}{cc}
\Phi-I & \Gamma \\
\Psi & 0
\end{array}\right]=n+1
$$

電学諭 $C, 119$ 巻 7 号, 平成 11 年
ここで、制御段数を $N$ とし， $N=n+k(k \geq 0) な る$ 任意な 值に対して，入力ベクトルを $\boldsymbol{u}_{k}$ ，伝達マトリクスを $G$ と

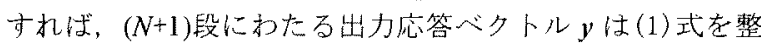
理して

$$
\boldsymbol{y}=\left[\bar{y}_{1}, \bar{y}_{2}, \cdots, \bar{y}_{N+1}\right]^{T}=G \boldsymbol{u}_{k}
$$

が得られる。ただし， $u_{k} 、 G$ は

$$
\boldsymbol{u}_{k}=\left[\bar{u}_{0}, \bar{u}_{1}, \cdots, \bar{u}_{N}\right]^{T}
$$

$$
G=\left[\begin{array}{cccc}
g_{1} & 0 & \cdots & 0 \\
g_{2} & g_{1} & \ddots & \vdots \\
\vdots & \vdots & \ddots & 0 \\
g_{N+1} & g_{N} & \cdots & g_{1}
\end{array}\right]
$$

である。

さらに，(N+1)段にわたる単位ステップ状の目標值ベクト ルを $i=[1,1, \cdots, 1]^{T}(N+1) \times 1$ とすれば，偏差ベタトルeは

$$
e=\left[e_{1}, e_{2}, \cdots, e_{N+1}\right]^{T}=\boldsymbol{i}-G u_{k}
$$

と表されるから， $Q, R$ を $(N+1) \times(N+1)$ なる正定対称な荷重 行列上して次式の偏差と操作量に関する2次形式評佂閏数 $P_{I}$ を定める。

$$
P_{I}=\frac{1}{2}\left(e^{T} Q e+u_{k}^{T} R u_{k}\right)
$$

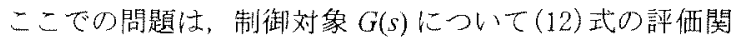
数老最小化す万最適有限整定操作量 $\boldsymbol{u}_{r k}$ を求如, この $\boldsymbol{u}_{r k}$ に 対する $G(s)$ の复 $\bar{y}_{i}(i=\mathbf{I} \sim N+1)$ を閉ルーブ采の規範モデ 儿灾答とし，目標値追従特性は $N$ 段で，外乱抑制特性は $n$ 段， $N^{\prime}$ 段で制御する 2 自由度最適有限整定サ一ボ系の設計 を行うことである。

\section{3. 有限整定操作量とパルス伝達関数}

目標值および制御対象の入力端に加わる外乱としてス テップ状信号考え，目標值に対する有限整定操作量を $\boldsymbol{u}_{r}$ ，外乱に刘方有限整定操作量を $\boldsymbol{u}_{d}$ とする。本章では $\boldsymbol{u}_{r}, \boldsymbol{u}_{d}$ の簡単な導出と (2) 式のパルス伝達関数 $G(z)$ の関係 在示古。

〈3・1〉目標値に対する最適有限整定操作量 $u_{r k}$ 図 1 (a)に示吉上らに，零次ホールド回路を前置した制御対 象について制御段数を $N=n+k(k \geq 0)$ 上子る。 $u_{i}(i=0,1, \cdots$, $N-1)$ なる操作量で制御対象の出力店答 $y_{i}(i \geq 1)$ 老 $N$ 段以降 ステッブ状目標值に有限整定させたとすれば， $y_{1}=1.0(i \geq$ N)， $u_{N+j}=u_{N}(j \geq 1)$ の関係式が得られる。民こで（1）式 に技方 $y_{i}\left(i=N, \cdots, N+n: y_{0}=0\right)$ に対し，この2つの条件 在代入し整理して行列表示守扎ば次式在得万。

$$
\boldsymbol{i}_{r}=J_{\dot{k}} \boldsymbol{u}_{r k}=[1,1, \cdots, 1]^{T} \quad(n+1) \times 1
$$


ただし，Iは単位行列であり，Wは次式で表される。

(a)

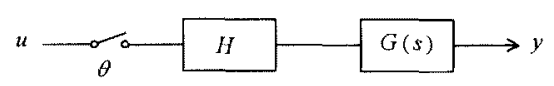

(b)

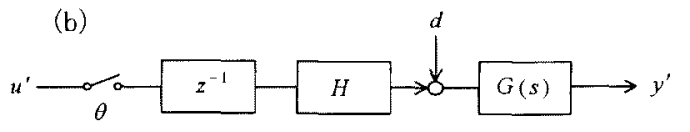

図 1 開ループ亲

Fig. 1. Open loop system.

ただし， $u_{r k}$ は(9)式で与えており，J

$$
J_{k}=\left[\begin{array}{cccccccc}
g_{N} & g_{N-1} & \cdots & g_{n+1} & g_{n} & \cdots & g_{1} & 0 \\
g_{N+1} & g_{N} & \cdots & g_{n+2} & g_{n+1} & \cdots & g_{2} & h_{1} \\
\vdots & \vdots & & \vdots & \vdots & & \vdots & \vdots \\
g_{N+n} & g_{N+n-1} & \cdots & g_{2 n+1} & g_{2 n} & \cdots & g_{n+1} & h_{n}
\end{array}\right] \text { (14) }
$$

ここで，制御段数と系の次数が等しい場合には $k=0$ とお いて $N=n$ であるから， $J_{k}=J_{0}$ は $(n+1) \times(n+1)$ 行列となり， $\left|J_{0}\right| \neq 0$ が成立し，(13)式から

$$
u_{r 0}=J_{0}^{-1} i_{r}=\left[u_{0}, u_{1}, \cdots, u_{n}\right]^{T}
$$

が求まり，知 は目標值変化に対する最短有限整定操作量で ある。ただし，J日次式で表され，この場合 $(i=n \sim 2 n)$ の $y_{i}$ について整理している。

$$
J_{0}=\left[\begin{array}{cccc}
g_{n} & \cdots & g_{1} & 0 \\
g_{n+1} & \cdots & g_{2} & h_{1} \\
\vdots & & \vdots & \vdots \\
g_{2 n} & \cdots & g_{n+1} & h_{n}
\end{array}\right] \quad(n+1) \times(n+1)
$$

次に，(15）式で得られる最短時間有限整定操作量 $\boldsymbol{u}_{r 0}$ 之 ハルス伝達関数 $G(z)$ のパラメータ $a_{i}, b_{i}(i=1 \sim n)$ の関係式 を求める。まず (15)式を求めたときのiの值老 1 段准めて $y_{i}(i=n+1 \sim 2 n+1)$ について整理し行列表示すれば,

$$
i_{r}=J_{1} \boldsymbol{u}_{r j} \quad(n+1) \times 1
$$

を得る。ただし，Jは(4)式の関保を用いて次式の右辺 2 項 のように変形できる。

$$
J_{1}=\left[\begin{array}{cccc}
g_{n+1} & \cdots & g_{2} & h_{1} \\
g_{n+2} & \cdots & g_{3} & h_{2} \\
\vdots & & \vdots & \vdots \\
g_{2 n+1} & \cdots & g_{n+2} & h_{n+1}
\end{array}\right]=J_{0} W{ }_{(n+1) \times(n+1)}
$$

よって，(15)式から $i_{r}=J_{0} u_{r 0}$ であり（17）式との差を考え れば次式を得る。

$$
J_{i j}(I-W) \boldsymbol{\mu}_{r i}=\mathbf{0}
$$

$$
W=\left[\begin{array}{ccccc}
-a_{1} & 1 & 0 & \cdots & 0 \\
-a_{2} & 0 & 1 & \ddots & \vdots \\
\vdots & \vdots & \ddots & \ddots & 0 \\
-a_{n} & 0 & \cdots & 0 & 1 \\
0 & 0 & \cdots & 0 & 1
\end{array}\right] \quad(n+1) \times(n+1)
$$

ここで，(19)式の両辺に $J_{0}^{-1}\left(\left|J_{0}\right| \neq 0\right)$ を作用させれば

$$
(I-W) \boldsymbol{u}_{r 0}=\mathbf{0}
$$

が得られ，上式を船けば操作量 $u_{i}(i=0 \sim n)$ とパルス伝達関 数 $G(z)$ のパラメータ $a_{i}, b_{i}$ の間には

$$
\begin{aligned}
& a_{i}=\left(u_{i}-u_{i-1}\right) / u_{0} \\
& b_{i}=\left(y_{i}-y_{i-1}\right) / u_{0} \\
& \quad\left(u_{0}=1 / \sum_{j=1}^{n} b_{j}, u_{i}=\left(1+\sum_{j=1}^{i} a_{j}\right) u_{0}\right)
\end{aligned}
$$

なる関係式が得られる14)。ただし， $y_{i}$ は $u_{i}$ に対する制御対 象の有限整定応答であり，(1)，(8)式から得られる。

一方, $N \neq n(k \neq 0)$ の場合には，Jは $J_{k}(14)$ 式のように $(n+1) \times(N+1)$ 行列で $\operatorname{rank} J_{k}=(n+1)$ となり $u_{r k}$ は一意に定まら ない。そこで，(13）式の拘束条件 $\boldsymbol{i}_{r}-J_{k} \boldsymbol{u}_{r k}=\mathbf{0}$ の下で(12) 式 の評価を最小化する操作量をラグランジェの未定係数法を 用いて求めれ杖，最適有限整定操作量 $\boldsymbol{u}_{r k}$ が次式の上うに 得られる。11)

$$
\begin{gathered}
\boldsymbol{u}_{r k}=M^{-1}\left[G^{T} Q i-J_{k}^{T}\left[J_{k} M^{-1} J_{k}^{T}\right]^{-1}\left[J_{k} M^{-1} G^{T} Q i-i_{r}\right]\right] \\
=\left[\bar{u}_{0}, \bar{u}_{1}, \cdots, \bar{u}_{N}\right]^{T} \\
\left(M=\left[R+G^{T} Q G\right]\right)
\end{gathered}
$$

ここで，(22)式を求めたと同様にして，(23)式から得ら 机る最適有限整定操作量 $\bar{u}_{i}(i=0 \sim N)$ に対する制御刘象の 出力応答を $\bar{y}_{i}$ とすれば,

$$
\begin{aligned}
& \bar{a}_{i}=\left(\bar{u}_{i}-\bar{u}_{i-1}\right) / \bar{u}_{0} \\
& \bar{b}_{i}=\left(\bar{y}_{i}-\bar{y}_{i-1}\right) / \bar{u}_{0}
\end{aligned} \quad\left(\bar{u}_{0}=1 / \sum_{j=1}^{N} \bar{b}_{j}\right)
$$

が得られ， $\bar{a}(z)=\sum_{i=1}^{N} \bar{a}_{i} z^{-i}, \bar{b}(z)=\sum_{i=1}^{N} \bar{b}_{i} z^{-t}$ として $\bar{G}(z)=\bar{b}(z) /[1+$ $\bar{a}(z)]$ なるオーバパラメータモデルが実現できる。このモ デル $\bar{G}(z)$ は追加された極と零点が相殺していることか 5 ,

$$
\bar{G}(z)=\frac{\bar{b}(z)}{1+\bar{a}(z)}=\frac{b(z) \lambda(z)}{[1+a(z)] \lambda(z)}
$$


を満足する $\lambda(z)$ が存在し，(25)式の右辺の分母どうしにつ

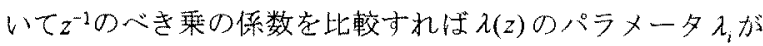
得られ

$$
\begin{gathered}
\lambda(z)=1+\sum_{i=1}^{k} \lambda_{i} z^{-i}, \quad \lambda_{i}=\bar{a}_{i}-\sum_{j=1}^{n} \lambda_{i-j} a_{j} \\
\left(i=1 \sim k, \lambda_{0}=1, \lambda_{p}=0 \quad(p<0)\right)
\end{gathered}
$$

と表せる。

また， $\bar{u}_{i}$ の系列と $\bar{u}_{i}$ に対する制御対象の出力灾答 $\bar{y}_{2}$ (規 範モデル応答）の系列老 $z$ 領域で表せば次式が得られる。

$$
\begin{aligned}
& \bar{u}(z)=[1+\bar{a}(z)] \bar{u}_{0} /\left(1-z^{-1}\right) \\
& \bar{y}(z)=\bar{u}_{0} \bar{b}(z) /\left(1-z^{-1}\right)
\end{aligned}
$$

〈3・2〉外乱に対する有限整定操作量 $u_{d j} \quad$ 図1(b)に 示す上うに，制御対象の入力端に単位ステップ状の外乱 $d$ が加わってから 1 サンプル周期遅れて操作量 $u_{i}^{\prime}(i=0 \sim n)$ を 与え, $n$ 段で出力灾答を零状態に有限整定応答させる。 のとき出力 $y_{i}^{\prime}$ について次式が成立している。

$$
y_{i}^{\prime}=h_{i}-\sum_{l=1}^{i-1} g_{i-i} u_{l-1}^{\prime} \quad\left(i \geq 1, g_{0}=0\right)
$$

ここに，hは外乱に対する制御対象のステッブ答であ り，n段で有限整定すれば $y_{i}^{\prime}=0(i \geq n+1) ， u_{j}^{\prime}=1.0(j \geq n)$ が成立する。この条件を(28)式の $y_{i}^{\prime}(i=n+1 \sim 2 n+1)$ に代入 し，整理してマトリクス表示すれば次式を得る。

$$
i_{d}=J_{0} \boldsymbol{u}_{d 0}
$$

ただし， $u_{d 0}=\left[u_{0}^{\prime}, u_{1}^{\prime}, \cdots, u_{n}^{\prime}\right]^{\top}$ であり， $i_{d}$ は次式で表される。

$$
\boldsymbol{i}_{d}=\left[h_{n+1}, h_{n+2}, \cdots, h_{2 n+1}\right]^{\top} \quad(n+1) \times 1
$$

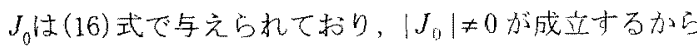

$$
u_{d 0}=J_{0}^{-1} i_{d}=\left[u_{0}^{\prime}, u_{1}^{\prime}, \cdots, u_{n}^{\prime}\right]^{T}
$$

として，スデップ状外乱に対する最短時間有限整定操作量 $\boldsymbol{u}_{d 0}$ が得られる。

次に, 上式で得られる最短時間有限整定操作量 $u_{i}^{\prime}(i=$ $0 \sim n)$ とバルス伝澾関数 $G(z)$ のパラメータ $a_{i}, b_{i}(i=1 \sim$

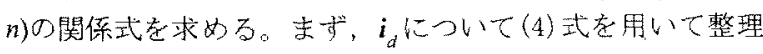
すれば,

$$
\left.i_{d}=\left[\begin{array}{c}
h_{n+1} \\
h_{n+2} \\
\vdots \\
\vdots \\
h_{2 n+1}
\end{array}\right]=J_{0}\left[\begin{array}{c}
1 \\
1 \\
\vdots \\
\vdots \\
1
\end{array}\right]-\left[\begin{array}{c}
a_{1} \\
a_{2} \\
\vdots \\
a_{n} \\
0
\end{array}\right]\right]
$$

となり，上式の雨辺に左側から $J_{0}{ }^{-1}$ 作用させれば

$$
\boldsymbol{u}_{d 0}=\left[1-a_{1}, 1-a_{2}, \cdots, 1-a_{n}, 1\right]^{T}
$$

なる関倸式が得られ，

$$
a_{i}=1-u_{i-1}^{\prime}
$$

となる。この式を用いて，ステップ状外乱に対する最短時 間有限整定操作量の系列 $u_{i}^{\prime} z$ 領域で表せば,

$$
\begin{aligned}
u_{d 0}(z) & =u_{0}^{\prime}+u_{1}^{\prime} z^{-1}+\cdots+u_{n-1}^{\prime} z^{-(n-1)}+\frac{u_{n}^{\prime} z^{-n}}{1-z^{-1}} \\
& =\frac{1}{1-z^{-1}}-z a(z)
\end{aligned}
$$

が得られる。また（35）式の操作量を采に加えたときの出 力応答について，系に加わる実際の入力が

$$
\begin{aligned}
u_{d 0}(z) & =\frac{z}{1-z^{-1}}-\left[\frac{1}{1-z^{-1}}-z a(z)\right] \\
& =z[1+a(z)]
\end{aligned}
$$

となることから，外乱に対する最短有限整定唐答は

$$
\begin{aligned}
& y_{d}(z)=z^{-1} G(z) u_{d u}(z)=b(z) \\
& \left.\quad y_{i}^{\prime}=b_{i}: \quad i=1 \sim n\right)
\end{aligned}
$$

なる関保式が得られる。なお，操作量と制御量に関する2 次形式評洒を考えれば外乱に対する $N^{\prime}$ 段制御による最適有 限整定操作量 $\boldsymbol{u}_{d k^{\prime}}$ ，最適有限整定心答 $\bar{y}_{d}(z)$ む同様に求ま 万。（付録 II 参照）

以上の上うに，ステップ状目標值に対寸る最適有限整定 操作量 $\boldsymbol{u}_{r k}$ は(23)式から，またステッブ状外乱に対する最 短有限整定操作量 $\boldsymbol{u}_{d !}$ \&(31) 式加的得占れ，对応才る出力 応答 $\bar{y}(z), y_{d}(z)$ は执のおの(27)式，(37) 式として得られ 万。

次章で設計する 2 自由度鼠適有限整定制御系では，目標 值に対しては(27)式の $\bar{y}(z)$ 无，外乱に対しては(37)式の $y_{d}(z)$ ，最適の場合は (A5) 式の $\bar{y}_{d}(z)$ が閉ループ柔の出力応 答 (規範モデル応答) となるよう制御装犆が設部される。

\section{2 自由度最適有限整定サーボ系の設計}

図 2 に，2自由度鼠適有限整定サ一ボ系の構成を示主。 ここに，r，dはステップ状の目標值㧍よび外乱であり，e， 在偏差, $y$ を制御量, 主ループの積分器 $D_{e}(z)$ の出力信号 它 $w_{i}$ 上寸る。

目標值変化に対しては，フィードフォワード要素 $H_{0}$. 制御対象に前置した補償器 $G_{c}(z)$ 上ダイン $f_{r}(z)$ 状態 フィードバックで $N$ 段制御による最適有限整定制御系を構 


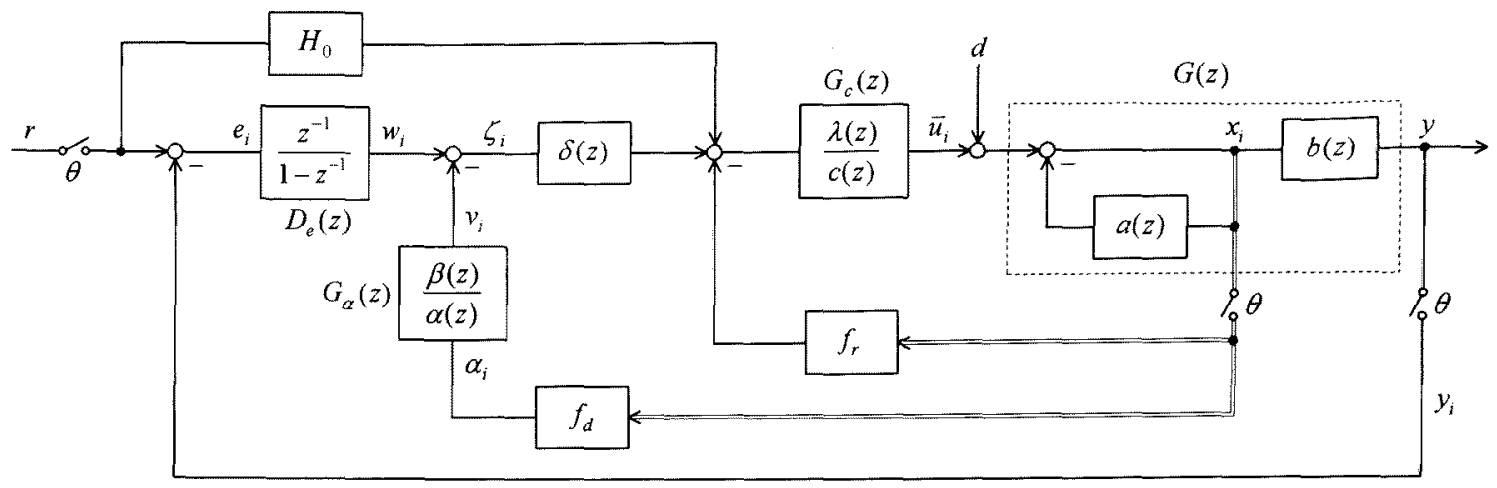

図 22 自由度最適有限整定サーボ系の構成

Fig. 2. Configuration of optimal deadbeat servo system with two-degree-of-freedon.

成する。この間, 外乱や制御対象のパラメータ変動がなけ れば， $D_{e}(z)$ の出力信号 $w_{i}$ ともう一つの局部フィードバッ ク補償器 $G_{\alpha}(z)$ の出力信号 $v_{i}$ が等しくなるよう $G_{\alpha}(z), f_{d}(z)$ が設計され $\zeta_{1}=0$ となって目標值変化に対しては積分補償 を含まないサーボ系を設計することとなる。

また，外乱に対しては主ループのダイン $\delta(z)$ を外乱抑制 フィードバックゲインと考え，n段制御で外乱を最短有限 整定させる制御系を設計する。

なお，付録に文献6)で萩原らが提案しだディジタル型 2 自由度LQIサーボ系”の制御構成を示している。図 2 の制御構成も基本的には同様な構成上なっているが，有限 整定制御を実現するため $G_{c}(z), G_{a}(z)$ が加わっているのが 大きな相違である。

〈4・1〉目標值に対する最適有限整定サ一ボ系＼cjkstart前 述のように図2に执いて，外乱やパラメータ変動がなく， $D_{e}(z)$ の出力信号 $w_{i}$ と $G_{\alpha}(z)$ の出力信号 $v_{i}$ が等しくなれば $\zeta_{j}=0$ となり，目標值変化に対しては積分補償を含まない サーボ系を考えることができる。

そこで, $\zeta_{i}=0$ とおいて目標值 $r$ と制御量 $\bar{y}$ の問の制御構 成を分離すれば図 3 が得られる。この閉ループ系のステッ

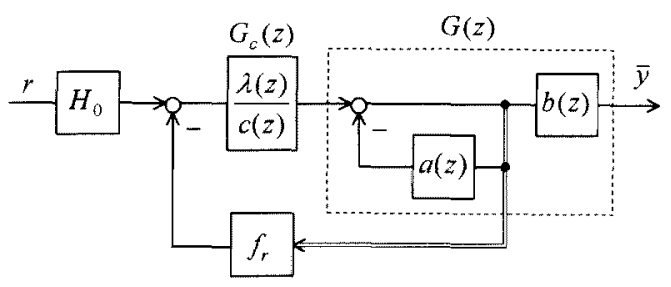

図 3 目標值に対寸る最適有限整定サ一ボ系

Fig. 3. Optimal deadbeat servo system for the step-wise desired value.
プ応答が(27)式の規範モデル応答と一致するように $G_{c}(z)$ のパラメータ $\lambda_{i}, c_{i}(i=1 \sim k)$ とフィードバックゲイン $f_{i}(i=$ 1〜n)を決定寸る。ここに, 前置補償器 $G_{c}(z)$, フィード バックダイン $f_{r}(z)$ を次式の上うに

$$
\begin{gathered}
G_{c}(z)=\frac{\lambda(z)}{c(z)}=\frac{1+\lambda_{1} z^{-1}+\cdots+\lambda_{k} z^{-k}}{1+c_{\mathrm{l}} z^{-1}+\cdots+c_{k} z^{-k}} \\
f_{r}(z)=f_{1} z^{-1}+f_{2} z^{-2}+\cdots+f_{n} z^{-n}
\end{gathered}
$$

とお忖ば、 $r-\bar{y}$ 間の合成伝達関数 $G_{r y}(z)$ は

$$
G_{\tilde{y}}=\frac{H_{0} \lambda(z) b(z)}{c(z)[1+a(z)]+\lambda(z) f_{r}(z)}=\frac{H_{0} \lambda(z) b(z)}{R(z)}
$$

となる。閏ループ系の制御量 $\bar{y}_{i}$ が有限制定㐫答するために は， $G_{\bar{y}}(z)$ のざての極を零に配置すればよいから $R(z)=$ 1が成立し次式の有限整定条件式が得られる。

$$
c(z)[1+a(z)]+\lambda(z) f_{r}(z)=1
$$

ここで，最適有限整定操作量 $\boldsymbol{u}_{r k}$ に対する規範モデル答 は(27) 式から $\bar{y}(z)=\bar{u}_{0} \bar{b}(z) /\left(1-z^{-1}\right)$ として得られ，この值 が $(40)$ 式のR(z)=1と利いた $G_{n \bar{y}}(z)$ の単位ステップ応答 $\bar{y}(z)$ $=H_{0} \lambda(z) b(z) /\left(1-z^{-1}\right)$ と一致すればよいから，次式

$$
\bar{y}(z)=\frac{\bar{u}_{0} \bar{b}(z)}{1-z^{-1}}=\frac{H_{0} \lambda(z) b(z)}{1-z^{-1}}
$$

が成立する。（25)式より $\bar{b}(z)=\lambda(z) b(z)$ であるから $G_{c}(z) \dot{\sigma}$ 分子 $\lambda(z)$ 柱オーバパラメータモデルの $\lambda(z)$ 上等しくなり， そのパラメータ $\lambda_{i}(i=1 \sim k)$ は (26) 式から定めればよい。ま た，図2のフィードフォワード要素 $H_{0}$ は $\boldsymbol{u}_{r k}$ の初段の值と 等しく 


$$
H_{0}=\bar{u}_{0}
$$

と決定できる。

従って, $\lambda(z)$ のパラメー夕は $\boldsymbol{u}_{r k}$ を用いて (26) 式から得ら

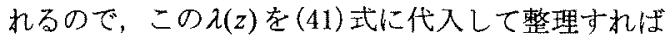

$$
\left.\left[\begin{array}{cccccccc}
{ }_{1} & 0 & \cdots & 0 & 1 & 0 & \cdots & 0 \\
\lambda_{1} & 1 & \ddots & \vdots & a_{1} & 1 & \ddots & \vdots \\
\lambda_{2} & \lambda_{1} & \ddots & 0 & a_{2} & a_{1} & \ddots & 0 \\
\vdots & \lambda_{2} & \ddots & 1 & \vdots & a_{2} & \ddots & 1 \\
\lambda_{k} & \vdots & \ddots & \lambda_{1} & a_{n} & \vdots & \ddots & a_{1} \\
0 & \lambda_{k} & & \lambda_{2} & 0 & a_{n} & & a_{2} \\
\vdots & \ddots & \ddots & \vdots & \vdots & \ddots & \ddots & \vdots \\
0 & \cdots & 0 & \lambda_{k} & 0 & \cdots & 0 & a_{n}
\end{array}\right]\left[\begin{array}{c}
f_{1} \\
f_{2} \\
\vdots \\
f_{n} \\
c_{1} \\
c_{2} \\
\vdots \\
c_{k}
\end{array}\right] \mid \begin{array}{c}
-a_{1} \\
-a_{2} \\
\vdots \\
-a_{n} \\
0 \\
\vdots \\
\vdots \\
0
\end{array}\right]
$$

が得られ，上式を解けば $G_{c}(z)$ の分母パラメータ $c_{i}(i=1 \sim$ k) 上フィードバックダイン $f_{i}(i=1 \sim n)$ が求まる。

さて，以上のように $G_{c}(z)=\lambda(z) / c(z), f_{r}(z), H_{0}$ が定まれ ば，ステップ状目標値信号に対し最適有限整定応答 $\bar{y}(z)$ が 得られるが、このとき図 2 における主ループの積分器 $D_{e}(z)$ の出力信号 $w_{i}$ と局部フィードバック補償器 $G_{\alpha}(z)=\beta(z) / \alpha(z)$ の出力信号 $v_{i}$ が等しくなり $\zeta_{i}=w_{i}-v_{i}=0$ となるように $G_{a}(z)$ とフィードバックグイン $f_{d}(z)$ を決定する。

最適有限整定操作量 $\bar{u}(z)$ 上対応寸る規範モデル答 $\bar{y}(z)$ は(27) 式から， $\bar{u}(z)=[1+\bar{a}(z)] \bar{u}_{0} /\left(1-z^{-1}\right), \bar{y}(z)=\bar{u}_{0} \bar{b}(z) /(1-$

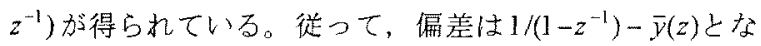
るから積分器 $D_{e}(z)=z^{-1} /\left(1-z^{-1}\right)$ の出力信号は

$$
\left(\frac{1}{1-z^{-1}}-\frac{\bar{u}_{0} \bar{b}(z)}{1-z^{-1}}\right) \frac{z^{-1}}{1-z^{-1}}=\frac{z^{-1}\left[1-\bar{u}_{0} \bar{b}(z)\right]}{\left(1-z^{-1}\right)^{2}}
$$

となる。また, $\bar{u}(z)=[1+\bar{a}(z)] \bar{u}_{0} /\left(1-z^{-1}\right)$ なる操作量に対す る制御対象の状態值 $\boldsymbol{x}(z)$ は

$$
\frac{1}{1+a(z)} \cdot \frac{[1+\bar{a}(z)] \bar{u}_{0}}{1-z^{-1}}=\frac{\lambda(z) \bar{u}_{0}}{1-z^{-1}}
$$

として得られる。局部補償器 $G_{\alpha}(z)$ を次式のように

$$
G_{\alpha}(z)=\frac{\beta(z)}{\alpha(z)}=\frac{\beta_{0}+\beta_{1} z^{-1}+\cdots+\beta_{N-1} z^{-(N-1)}}{\alpha_{0}+\alpha_{1} z^{-1}+\cdots+\alpha_{k+1} z^{-(k+1)}}
$$

と定義すればフィードバックゲインを $f_{d}(z)$ として $G_{\alpha}(z)$ の 出力信号は

$$
\frac{\beta(z)}{\alpha(z)} \cdot f_{d}(z) \frac{\lambda(z) \bar{u}_{0}}{1-z^{-1}}
$$

となる。よって，1段遟れた (48) 式と (45) 式を等しくおけ ば

$$
\frac{\left[1-\bar{u}_{0} \bar{b}(z)\right]}{\left(1-z^{-1}\right)^{2}}=\frac{\beta(z)}{\alpha(z)} \cdot \frac{f_{d}(z) \lambda(z) \bar{u}_{0}}{\left(1-z^{-1}\right)}
$$

となるから，

$$
G_{\alpha}(z)=\frac{\beta(z)}{\alpha(z)}=\frac{\left[1-\bar{u}_{0} \bar{b}(z)\right] /\left(1-z^{-1}\right)}{f_{d}(z) \lambda(z) \bar{u}_{0}}
$$

として $G_{\alpha}(z)$ が定まる。ここで $f_{d}(z)$ は任意に選べるが次節 〈4・2〉で外乱に対寸る補償器 $\delta(z)$ の設計を考慮して

$$
f_{d}(z)=\left(1-z^{-1}\right) / \bar{u}_{0}
$$

と定めれば

$$
\begin{aligned}
& \alpha(z)=\left(1-z^{-1}\right) \lambda(z) \\
& \beta(z)=\left[1-\bar{u}_{0} \bar{b}(z)\right] /\left(1-z^{-1}\right)
\end{aligned}
$$

のように $\alpha(z), \beta(z)$ が決定できる。

なお， $\beta(z)=\left[1-\bar{u}_{0} \bar{b}(z)\right] /\left(1-z^{-1}\right)$ は偏差の系列であり $(N$

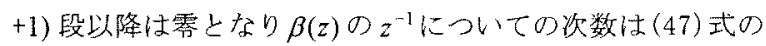
ように $(N-1)$ 次とすればよい。

(a)
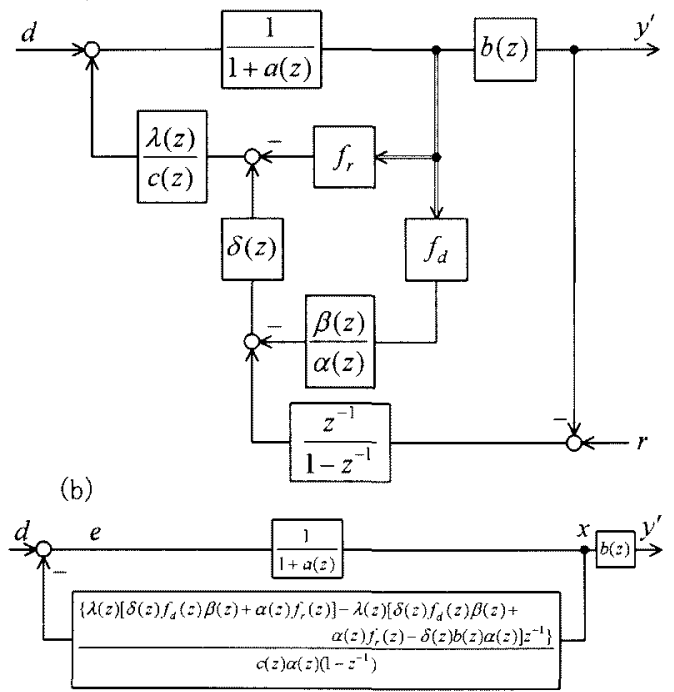

図 4 外乱に対する有限整定サーボ采とその等 価ブロック線図

Fig. 4. Deadbeat servo system for the step-wise disturbance and equivalent block diagram. 
〈4・2〉外乱に対する最短有限整定制御前節で得 られた (43)，(44)，(51)，(52) 式から $H_{0} ， G_{c}(z), f_{r}(z), f_{d}(z)$, $G_{a}(z) を$ 定めれば目標值変化に対し主ループの積分器を用 いない最適有限整定サ一ボ系が実現できる。一方，外乱や パラメータ変動に対しては図 $20 \zeta \neq 0$ となるから，補償 器 $\delta(z)$ を用いてステップ状外乱に対し最短で制御量を零状 態にもどす外乱抑制特性をもったサーボ系を設計する。

図 2 において $r=0$ とし，外乱 $d$ と刘灾寸る制御量 $y^{\prime}$ に つての関倸を整理すると図4(a)となり，さらに等価変 換を行艺図 $4(\mathrm{~b})$ となる。よって, $d-y^{\prime}$ 間の伝详関数 $G_{d y^{\prime}}(z)$ は (41) 式の有限整定条件と (51)，(52) 式の $f_{d}(z)$, $\alpha(z), \beta(z)$ を代入すれば次式を得る。

$$
\begin{aligned}
G_{d y^{\prime}}(z) & =\frac{c(z) \alpha(z) b(z)\left(1-z^{-1}\right)}{\left\{( 1 - z ^ { - 1 } ) \left[c(z) \alpha(z)[1+a(z)]+\lambda(z)\left[\delta(z) f_{d}(z) \beta(z)+\right.\right.\right.} \\
& =\frac{\left.\left.\left.\alpha(z) f_{r}(z)\right]+\alpha(z) \delta(z) \bar{b}(z) z^{-1}\right]\right\}}{\left\{c(z)\left(1-z^{-1}\right)[1+a(z)]+\frac{\delta(z) z^{-1}}{\bar{u}_{0}}-\frac{\delta(z) \bar{u}_{0} \bar{b}(z) z^{-1}}{\bar{u}_{0}}+\right.} \\
& =\frac{\left.\left(1-z^{-1}\right) \lambda(z) f_{r}(z)+\delta(z) \bar{b}(z) z^{-1}\right\}}{\left(1-z^{-1}\right)\left\{c(z)[1+a(z)]+\lambda(z) f_{r}(z)\right\}+\delta(z) z^{-1} / \bar{u}_{0}} \\
& =\frac{c(z) b(z) \bar{u}_{0}\left(1-z^{-1}\right)}{\left(1-z^{-1}\right) \bar{u}_{0}+\delta(z) z^{-1}}
\end{aligned}
$$

ところで，外乱に対する最短時間有限整定操作量 $\boldsymbol{u}_{d 0}$ に 対する制御対象の出力店答は (37) 式から $y_{d}(z)=b(z)$ である から，(53)式の伝達関数 $G_{d y^{\prime}}(z)$ に単位ステップ状の外乱 $1 /\left(1-z^{-1}\right)$ 加加った応答 $y^{\prime}(z)$ と等しくおける。よって

$$
y^{\prime}(z)=\frac{c(z) b(z) \bar{u}_{0}\left(1-z^{-1}\right)}{\left(1-z^{-1}\right) \bar{u}_{0}+\delta(z) z^{-1}} \cdot \frac{1}{\left(1-z^{-1}\right)}=b(z)
$$

が成立する。上式から $\delta(z) z^{-1}=\bar{u}_{0}\left[c(z)-\left(1-z^{-1}\right)\right]$ となり整理 すれば

$$
\delta(z)=\bar{u}_{0}\left[\left(1+c_{1}\right)+c_{2} z^{-1}+\cdots+c_{k} z^{-(k-1)}\right]
$$

が求まる。なお，外乱に対し $N^{\prime}$ 段での最適有限整定特性 を得るには付録【に示す上うに $\delta(z)$ 在決定寸ればよい。

以上の上うに設計された図 2 の制御構成による 2 自由度 最適有限整定サーボ系の設計手頌を改めて整理すれば次の ようになる。
1) 制御対象のステップ応答のサンプル值を用いて, (15)，(23) 式から最短および最適有限整定操作量 $\boldsymbol{u}_{r 0}$ 䄈索求め, $H_{0}=\bar{u}_{0}$ とおく。

2）(22),(24)式から制御対象およびオーバパラメータ モデルのパルス伝達関数 $G(z)=b(z) /[1+a(z)], \bar{G}(z)$ $=\bar{b}(z) /[1+\bar{a}(z)]$ を求め，同時に(26)式から $G_{c}(z)$ の 分子パラメータ $\lambda_{i}(i=1 \sim k)$ を求める。

3）(44)式から，フィードバックゲイン $f_{i}(i=1 \sim n)$ と $G_{c}(z)$ の分母パラメータ $c_{j}(j=1 \sim k)$ を求める。

4) $f_{d}(z)=\left(1-z^{-1}\right) / \bar{u}_{0}$ とおき $\alpha(z), \beta(z)$ を(52) 式から 求め, $G_{\alpha}(z)$ を定める。

5） $c_{j}(j=1 \sim k)$ を用いて (55) 式から $\delta(z)$ を求める。 (外乱に対する最適応答を得万場合は付録 II，(A7) 式の $\delta^{\prime}(z)$ を用いる)

1)～5)の過程により $H_{0}, \lambda(z), f_{r}(z), c(z), f_{d}(z), \alpha(z), \beta(z)$, $\delta(z)$ の各補償要素が定まり図 2 のーボ系が構成できる。

\section{5. 設計例}

制御対象の伝達関数が $G(s)=5 /(1+2 s)(1+3 s)(1+7 s)$ で表さ れる 3 次の系を考える。制御段数 $N=5(k=2)$ の場合にお ける 2 自由度最適有限整定応答サーボ系の設計例とシミュ レーション図を示す。

サンプル周期を $\theta=1.5 \mathrm{sec}$ とすれば制御対象のステップ 态答 $h(t)$ のサンプル值から，(4) 式の $g_{i}$ は $g_{1}=0.047, g_{2}=$ $0.219, g_{3}=0.382, g_{4}=0.477, \cdots$ を得る。よって, $N=n=$ 3 の場合にお打る最短有限整定操作量 $\boldsymbol{\mu}_{r 0}$ は (15) 式から

$$
\boldsymbol{u}_{r 0}=\left[u_{0}, u_{1}, u_{2}, u_{3}\right]^{T}=[4.995,-4.425,1.355,0.200]^{T}
$$

となる。この $u_{i}(i=0 \sim 3)$ に対する出力応答は(1)式から $y_{1}$ $=0.234, y_{2}=0.888, y_{3}=1.0$ が求まり，(22) 式から制御対象 のパルス伝達関数は

$$
G(z)=\frac{0.047 z^{-1}+0.131 z^{-2}+0.023 z^{-3}}{1-1.886 z^{-1}+1.157 z^{-2}-0.231 z^{-3}}
$$

となる。一方, $N=5(k=2)$ の場合，(12)式の評価関数にお ける荷重行列を $Q=R=I$ (I: 単位行列) と選心゙ば, 最適有限 整定操作量 $\boldsymbol{u}_{r k}$ は(23) 式から得られ，対応するオ一バパラ メータモデル $\bar{G}(z)$ は(24) 式から

$$
\boldsymbol{u}_{r k}=[1.506,0.764,-0.062,-0.601,0.521,0.200]^{T}(58)
$$

$$
\begin{aligned}
\bar{G}(z)=\frac{0.047 z^{-1}+0.196 z^{-2}+0.248 z^{-3}}{1-0.493 z^{-1}-0.548 z^{-2}-0.358 z^{-3}} * \\
* \frac{+0.152 z^{-4}+0.021 z^{-5}}{+0.745 z^{-4}-0.213 z^{-5}}
\end{aligned}
$$

として求まる。よって，(57)，(59)式の $a_{i}(i=1 \sim n), \bar{a}_{j}(j=$ 1〜N) 在用いれば(26)式から 


\section{表 1 数值例}

Table 1. Numerical examples.

\begin{tabular}{|c|c|c|c|c|c|c|c|c|c|c|}
\hline & & $(s)$ & $(1+2$ & $s)(1+$. & $3 s)(1+$ & & & & & \\
\hline & \begin{tabular}{|l|l}
$N$ & $i$ \\
\end{tabular} & $u_{i}$ & $a_{i}$ & $b_{i}$ & $y_{i}$ & & & & & \\
\hline (a) & 70 & 4.995 & 7 & 7 & 0.000 & & & & & \\
\hline & 1 & -4.425 & -1.886 & 0.047 & 0.234 & & & & & \\
\hline & 2 & 1.355 & 1.157 & 0.131 & 0.888 & & & & & \\
\hline & 3 & 0.200 & -0.231 & $\overline{0.023}$ & 1.000 & & & & & \\
\hline & $i$ & $\overline{u_{i}}$ & $\overline{\bar{a}}_{i}$ & $\overline{\bar{b}_{1}}$ & $\bar{y}_{i}$ & $\lambda_{i}$ & $c_{i}$ & $\overline{f_{i}}$ & $\alpha_{i}$ & $\overline{\beta_{i}}$ \\
\hline$\left|\begin{array}{ll}\mid .5 \\
s e c\end{array}\right|$ & 0 & 1.505 & 7 & 7 & 0.000 & 1.000 & & & 1.000 & \begin{tabular}{|l|}
1.000 \\
\end{tabular} \\
\hline & 1 & 0.764 & -0.493 & 0.047 & 0.071 & 1.393 & 1.134 & 0.752 & 0.393 & 0.929 \\
\hline & 52 & -0.062 & -0.548 & 0.196 & 0.366 & 0.922 & 0.555 & -0.622 & -0.471 & 0.634 \\
\hline & 3 & -0.601 & -0.358 & 0.248 & 0.740 & & & 0.139 & -0.922 & 0.260 \\
\hline & 4 & 0.521 & 0.745 & 0.152 & 0.970 & & & & & 0.031 \\
\hline & 5 & 0.200 & -0.213 & 0.021 & 1.000 & & & & & 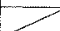 \\
\hline (b) & $i$ & $u_{i}$ & $a_{i}$ & $b_{i}$ & $y_{i}$ & & & & & \\
\hline & 0 & 1.168 & 7 & 7 & 0.000 & & & & & \\
\hline & 31 & $\mid-0.283$ & -1.242 & 0.266 & 0.311 & & & & & \\
\hline & 2 & 0.262 & 0.467 & 0.528 & 0.928 & & & & & \\
\hline & 3 & 0.200 & -0.053 & 0.062 & 1.000 & & & & & \\
\hline & it & $\bar{u}_{i}$ & $\bar{a}_{i}$ & $\bar{b}_{t}$ & $\bar{y}_{i}$ & $\lambda_{4}$ & $c_{i}$ & $f_{i}$ & $\alpha_{i}$ & $\bar{\beta}$ \\
\hline & 0 & 0.665 & 7 & 7 & 0.000 & 1.000 & 7 & 7 & 1.000 & 1.000 \\
\hline & 1 & 0.247 & -0.628 & 0.266 & 0.177 & 0.614 & 0.543 & 0700 & -0.386 & 0.823 \\
\hline & $5 \sqrt{2}$ & 0.146 & -0.152 & $f_{0.692}$ & 0.637 & 0.144 & 0.111 & -0.333 & -0.471 & 0.363 \\
\hline & 3 & 0.182 & 0.055 & 0.424 & 0.919 & & & 0.041 & -0.144 & 0.081 \\
\hline & 4 & 0.205 & 0.034 & 0.114 & 0.994 & & & & 7 & 0.006 \\
\hline & 5 & 0.200 & -0.008 & 0.009 & 1.000 & & & & 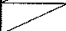 & 7 \\
\hline
\end{tabular}
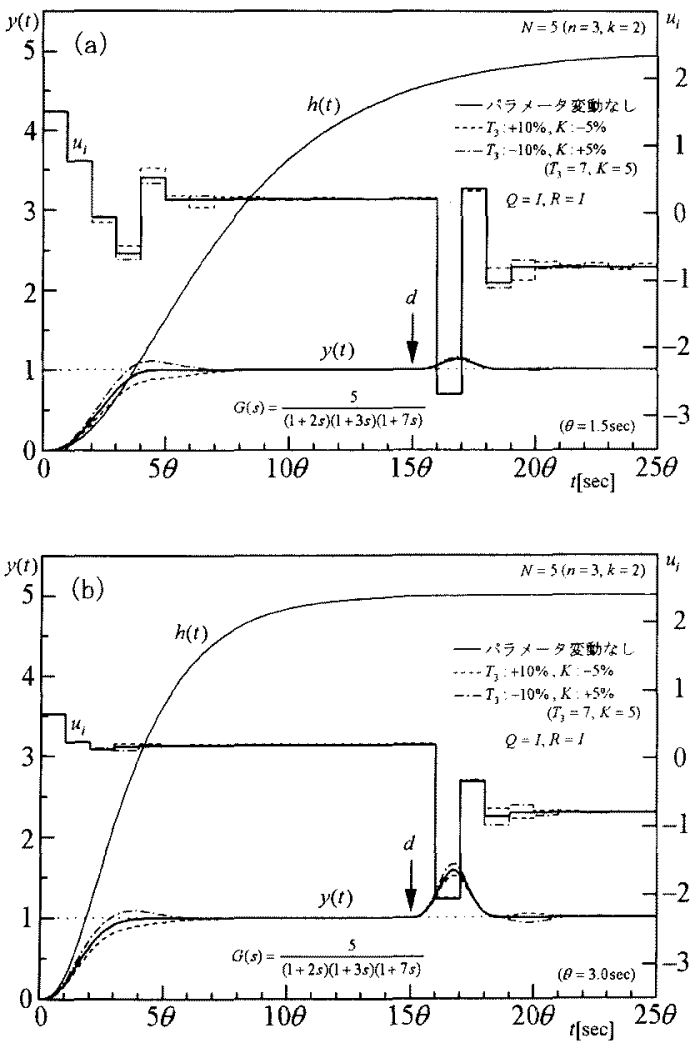

図 5 シミュレーション結果

Fig. 5. Simulation results. $\lambda(z)=1+1.393 z^{-1}+0.922 z^{-2}$

仿得られ，(44)式に $\lambda_{i}(i=1 \sim k)$ の值を代入すれば

$$
\left[\begin{array}{l}
f_{1} \\
f_{2} \\
f_{3} \\
c_{1} \\
c_{2}
\end{array}\right]=\left[\begin{array}{lllll}
1 & 0 & 0 & 1 & 0 \\
\lambda_{1} & 1 & 0 & a_{1} & 1 \\
\lambda_{2} & \lambda_{1} & 1 & a_{2} & a_{1} \\
0 & \lambda_{2} & \lambda_{1} & a_{3} & a_{2} \\
0 & 0 & \lambda_{2} & 0 & a_{3}
\end{array}\right]^{-1}\left[\begin{array}{c}
-a_{1} \\
-a_{2} \\
-a_{3} \\
0 \\
0
\end{array}\right]
$$

から $f_{i}(i=1 \sim 3)$ と $c_{j}(j=1 \sim 2)$ が求まり，(52)式から $\alpha_{i}(i$ $=1 \sim k+1), \beta_{j}(j=0 \sim N-1),(55)$ 式加ら $\delta(z)$ が決定でき る。こ扎の值を表 1(a)に示した。また，サンプル周期 $\theta=3 \sec の$ 場合についても同様に各パラメータを求め表 1 (b)に示した。

以上のように設計された制御装置 $G_{c}(z), G_{\alpha}(z), f_{d}(z)$, $f_{r}(z)$ を用いて図202自由度最適有良整定制御系を構成し た場合のシミュレーション結果を図 5 (a)，(b)に示す。同 図 (a) は $\theta=1.5 \mathrm{sec}$ の場合，(b)は $\theta=3 \mathrm{sec}$ の場合のステッ プ状目標值変化に対する閉ループ亲の応答と15 $\theta$ の時点で 単位ステップ状の外乱を加えた場合の応答である。

実線はパラメータ変動のない場合であり，設計どおり目 標值に対しては $N=5$ 段, 外乱に対しては $n=3$ 段で有限整

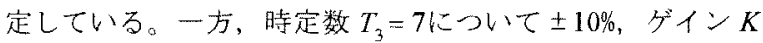
=5について干 $5 \%$ のパラメータ変動を与えた場合の応答を 各々破線と一点鎖線で示しているが，いずれも安定な制御 結果が得られている。なお，目標值および外乱に対して 各々独立に最適有限整定応答を得る場合の設計例を2次振 動系制御対象について付録 IIに示守。

\section{6. まとめ}

本論文では，ステップ状目標值に対する追従特性の改善 と制御対象のパラメータ変動や定值外乱に対する積分補償 を独立に設計できる 2 自由度最適有限整定応答サーボ系の 設計法を提案した。

本手法は，制御対象のステップ応答を用いた簡単な行列 演算加 5 ，偏差と操作量に関卞る2 次形式評価を最小化寸 万最適有限整定操作量 $\boldsymbol{u}_{r \mathrm{r}}$ を求め， $\boldsymbol{u}_{r k}$ に対寸可制御対象の 出力応答 $\vec{y}_{i}$ 老規範モデル応答とし，この規範モデル応答に 閉ループ系のステップ応答が一致するように1形の最適有 限整定灾答サーボ采を設計している。また，外乱に対して は操作量と制御量に閔する 2 次形式評価を最小化する最適 有限整定操作量 $\boldsymbol{u}_{c k}$ ，求め，对応寸る応答 $\bar{y}^{\prime}$ を得るサーボ 系の設計であり，目標値と外乱について各々独立に最適有 限整定忍答が得られるサーボ采を設計している。

従来の手法では，操作量や偏差についての荷重行列を適 当に定め制御装置を設計後に閉ループ系の応答を求めて試 行を繰り返す必要があるのに対し，提案した手法は最適有 限整定操作量 $\boldsymbol{u}_{r k} ， \boldsymbol{u}_{d k^{\prime}}$ に対する応答が制御仕様者満たして 
いるか事前に確認してから制御装置を求め孙よ゙く設計法 も簡単である。

(平成 10 年 7 月 27 日受付, 平成 11 年 3 月 16 日再受付) 文 献

（1）朴・踰木・藤井：「多变数線形最適サ一ボ系の設㖕」、計測自動制御学 会端文集，Vol.8，No. 5，568/575（1972)

（2）池田・須田：「楮分型最適サ一ボ系の 2 自由度粠成」，第31回自動制御 連合讙演会前刷。115/116 (1988)

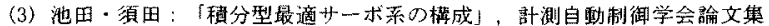
Vol.24, No. 1, 40/46 (1988)

(4) 藤崎・池田：「2自由度矰分型最適サ一术采の構成」、郡測自動制御学 会碖文集，Vol. 27，No. 8，907/914 (1991)

（5）萩原・大谷・荒木：12 自由度 L Q I サ一ボ柔の設計法」，システム制 御情報学会論文誌、Vol. 4, N No, 12，501/510（1991）

（6）萩原・一木・金星・福光・荒木：〔ディジタル型 2 自由度 L Q I サ一ボ

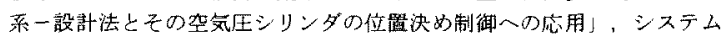
制御情報学会論文誌、Vol. 11，No. 2，51/60（1998）

（7）西村・米澤：〔綬和フィルタを用いる有限時間整定制御系の設計」，シ スデム制御情報学会論文誌，Vol.4，№. 10，399/406（1991）

（8）瓜倉・曼田：「過渡庶答を考慮した離散時間システムに対するデッドビ

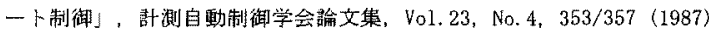

（9）舟橋・山田：「2自由度補㤨法に上るリップルフリ一最適デッドビート 制御!，計测自動制御学会諭文集，Vol. 27, Noo 1, 33/40 (1991)

（10）堀口・西村・医田・富田：「過度応答考慮した 2 自由度デッドビート 制御了，竍测自動制御学会袷文集，Vol. 25, No. 10，1046/1053 (1989)

(11) 村田・相良：〔インパルス応答を用いた最適有限整定応答制御装置の設 計」，計測自動制御学会論文集，Vol.20，№.12，1073/1080（1984）

(12)村田・相良・和田：「面列・フィードバック補借处よる有限整定応答制 御装置の設計」，計測自動制御学会諭文集，Vol. 20，No. 10，873/879 (1984)

(13) 村田・相良：〔状热フィードバックに上る最適有限整定制御系の設計」 電気学会論文誌，109-C，6，432/438（1989）

(14)野明・宮田・中野・村田：「最適有限整定サ一ボ系の外乱特性につい で，電気学会淪安誌，118-C，4，528/535（1998)

付 録 I

文献6)で萩原らにより提案されているディジタル型 2 自 由度LQI サーボ系の構成を下図に示す。

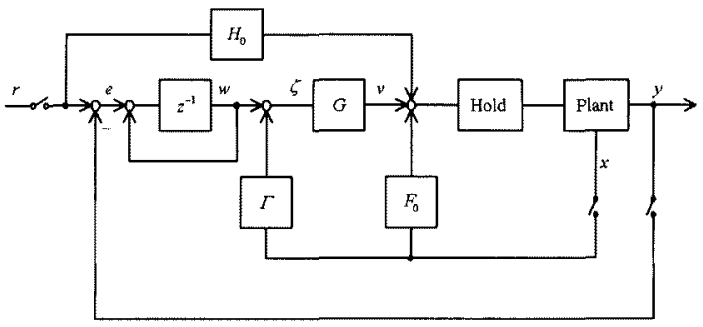

付 録 II

外乱に対する最適有限整定操作量と 2 自由度开一ボ系の コントローラ $\delta^{\prime}(z)$

1) 外乱に対する最適有限整定操作量 $\boldsymbol{u}_{d k^{\prime}}$ 制御段数を $N^{\prime}=n+k^{\prime}\left(k^{\prime} \geq 1\right)$ とし，ステップ状目標值に対し，出力忍答 $\boldsymbol{y}^{\prime}=\left[\vec{y}_{1}^{\prime}, \vec{y}_{2}^{\prime}, \cdots, \bar{y}_{N^{\prime}+1}^{\prime}\right]^{T}$ を有限時間で零状態に移す操作量 $\boldsymbol{u}_{d k^{\prime}}$ $=\left[\bar{u}_{0}^{\prime}, \bar{u}_{1}^{\prime}, \cdots, \bar{u}_{N^{\prime}}^{\prime}\right]^{T}$ 求めるため, 次式の制御量と操作量に関 卞る2 次形式評価関数 $P_{d}$ を定める。

$$
P_{d}=\frac{1}{2}\left(\boldsymbol{y}^{\prime T} Q^{\prime} \boldsymbol{y}^{\prime}+\boldsymbol{u}_{d k^{\prime}}^{T} R^{\prime} \boldsymbol{u}_{d k^{\prime}}\right)
$$

ここに， $Q^{\prime} ， R^{\prime}$ は $\left(N^{\prime}+1\right) \times\left(N^{\prime}+1\right)$ なる正定対称な荷重行列 であり，外乱に対する $(29)$ 式を求めたと同様に， $\bar{y}_{i}^{\prime}=0(i \geq$ $\left.N^{\prime}+1\right), \bar{u}_{i}^{\prime}=1.0\left(j \geq N^{\prime}\right)$ の条件から次式が得られる。

$$
i_{d k^{\prime}}=J_{k^{\prime}} u_{d k^{\prime}}
$$

ただし， $J_{k^{\prime}}$ は(14)式で $N=N^{\prime}$ としたものであり， $i_{d k^{\prime}}=\left[h_{N^{\prime}+1}\right.$, $\left.h_{N^{\prime}+2}, \cdots, h_{N^{\prime}+n+1}\right]^{T}$ である。 $J_{k^{\prime}}$ は $(n+1) \times\left(N^{\prime}+1\right)$ 行列で rank $J_{k^{\prime}}$

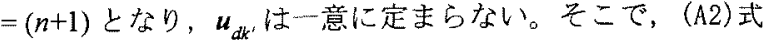
の拘束条件 $i_{d k^{\prime}}-J_{k^{\prime}} u_{d k^{\prime}}=0$ の下で(A1) 式の評価を最小化する 操作量をラグランジェの未定倸数法を用いて求めれば，外 乱に対する最適有限整定操作量 $\boldsymbol{u}_{d k^{\prime}}$ が次式のように得られ る。 ${ }^{11}$

$$
\begin{gathered}
\boldsymbol{u}_{d k^{\prime}}=M^{\prime-1}\left[G^{T} Q^{\prime} \boldsymbol{h}-J_{k^{\prime}}^{T}\left[J_{k^{\prime}} M^{\prime-1} J_{k^{\prime}}^{T}\right]^{-1}\left[J_{k^{\prime}} M^{\prime-1} G^{T} Q^{\prime} \boldsymbol{h}-\boldsymbol{i}_{d k^{\prime}}\right]\right] \\
\left(M^{\prime}=\left[R^{\prime}+G^{T} Q^{\prime} G\right], \boldsymbol{h}=\left[h_{2}, h_{3}, \cdots, h_{N^{\prime}+2}\right]^{T}\right)
\end{gathered}
$$

次に, オーバパラメータモデルを(26) 式と同様に $\bar{G}^{\prime}(z)=$ $\bar{b}^{\prime}(z) /\left[1+\bar{a}^{\prime}(z)\right]=b(z) \lambda^{\prime}(z) /[1+a(z)] \lambda^{\prime}(z)$ とすると，（A3)式で 得られる最適有限整定操作量 $\boldsymbol{u}_{d k^{\prime}}$ と $\bar{G}^{\prime}(z)$ のパラメータ $\bar{a}_{i}^{\prime}($ $\left.=1 \sim N^{\prime}\right)$ の間には，(33)式と同様に

$$
\begin{aligned}
u_{d k^{\prime}}=\left[1-\bar{a}_{1}^{\prime}, 1-\bar{a}_{2}^{\prime}, \cdots, 1-\bar{a}_{N^{\prime}}^{\prime}, 1\right]^{T} \\
\left(\bar{a}_{i}^{\prime}=1-\bar{u}_{i-1}^{\prime}, i=1 \sim N^{\prime}\right)
\end{aligned}
$$

なる関係式が得られる。また，ステップ状外乱に対する最 適有限整定応答 $\bar{y}_{i}^{\prime}$ は(28)式の関係から得られ， $\bar{y}_{i}^{\prime}=\bar{b}_{i}(i=1 \sim$ $\left.N^{\prime}\right)$ となるから $\bar{y}_{d}(z)$ は(37)式と同様に次式で表される。

$$
\bar{y}_{d}(z)=\bar{b}^{\prime}(z)
$$

なお， $\lambda^{\prime}(z)$ とそのパラメータ $\lambda_{i}^{\prime}\left(i=1 \sim N^{\prime}\right)$ は目標值の場合 について (26) 式を求好た同様にして， $\lambda^{\prime}(z)=1+\sum \lambda_{i}^{\prime} z^{-i}$ ， $\lambda_{i}^{\prime}=\bar{a}_{i}^{\prime}-\sum_{j=1}^{n} \lambda_{i-j}^{\prime} a_{j} \quad\left(i=1 \sim k^{\prime}, \lambda_{j}^{\prime}=1, \lambda_{p}^{\prime}=0(p<0)\right)$ が得られ る。

2) 外乱に対する最適補償器 $\delta^{\prime}(z)$ 外乱に対する最適有限 整定用の補償器 $\delta^{\prime}(z)$ を求める。外乱 $d$ 上出力 $\bar{y}^{\prime}$ の間の合 成伝達関数は (53)式で $G_{d y^{\prime}}(z)$ として与えられており，この $G_{a y^{\prime}}(z)$ に単位ステップ状外乱が加わった応答 $\bar{y}^{\prime}(z)$ と(A5) 式の外乱に対する規籍モデル応答 $\bar{y}_{d}(z)=b(z) \lambda^{\prime}(z)$ を等し くおけば次式が成立する。

$$
\bar{y}^{\prime}(z)=\frac{c(z) b(z) \bar{u}_{0}\left(1-z^{-1}\right)}{\left(1-z^{-1}\right) \bar{u}_{0}+\delta^{\prime}(z) z^{-1}} \cdot \frac{1}{\left(1-z^{-1}\right)}=b(z) \lambda^{\prime}(z)
$$

上式を $\delta^{\prime}(z)$ について整理すれば，最短時間の場合におけ る(55)式の $\delta(z)$ に対応して

$$
\delta^{\prime}(z)=\frac{\bar{u}_{0}\left[c(z)-\alpha^{\prime}(z)\right]}{z^{-1} \lambda^{\prime}(z)}
$$

が得られる。ただし， $\alpha^{\prime}(z)=\left(1-z^{-1}\right) \lambda^{\prime}(z)$ である。 
3) 数值例とシミュレーション結果 伝達関数が $G(s)=1 /$ $\left(1+0.4 s+s^{2}\right)$ で表される制御対象を考え, サンプル周期 $\theta$ $=0.5 \mathrm{sec}$, 制御段数を $N=4, N^{\prime}=3$ とする。 $R, R^{\prime}$ を $I$ (単 位行列)に固定し， $Q, Q^{\prime}$ をそれぞれ $I, 30 I, 100 I, 1000 I$ と したときの目標值に対する最適有限整定操作量 $\bar{u}_{i}$ と出力 $\bar{y}_{i}$ (i=0 4)を(23)，(8)式から求め表A1（a）に，外乱に対する 最適有限整定操作量 $\bar{u}_{j}^{\prime}$ と出力 $\bar{y}_{j}^{\prime}(j=0 \sim 3)$ を(A3), (A5) 式か ら求め表 $\mathrm{A} 1$ (b) に示した。また, 各々の開ループ系の応答 を図A1に示している。

ここで， $Q=30 I ， Q^{\prime}=100 I$ の場合を選び, 制御装置の設 計例を示す。制御対象 $G(z)$ と目標值および外乱に対する オーバパラメータモデル $\bar{G}(z), \bar{G}^{\prime}(z)$ の各々のパラメータと $\lambda(z), \lambda^{\prime}(z)$ のパラメータは表A2のように定まる。(44)式か ら, $f_{r}(z)=1.115 z^{-1}-0.702 z^{-2}, c(z)=1+0.482 z^{-1}+0.050 z^{-2}$ が求まり，(52) 式より $\alpha(z)=1-0.459 z^{-1}-0.483 z^{-2}-0.058 z^{-3}$, $\alpha^{\prime}(z)=1-0.843 z^{-1}-0.157 z^{-2}, \quad \beta(z)=1+0.677 z^{-1}+0.200 z^{-2}$ $+0.176 z^{-3}$ が得られる。この $c(z), \alpha^{\prime}(z), \lambda^{\prime}(z)$ を用いれ ば，(A7)式より， $\delta^{\prime}(z)$ が次のように求まる。

$$
\delta^{\prime}(z)=\frac{3.734+0.583 z^{-1}}{1+0.157 z^{-1}}
$$

なお, $\lambda(z), H_{0}, f_{d}(z)$ は本文 (26)，(43)，(51) 式から得られ る。

以上のように設計された制御装置を用いて図 2 の 2 自由 度最適有限整定サーボ系を構成し, シミュレーションを 行った結果を図A2に示す。

\section{表A1 最適有限整定操作量と規範モデル応答}

\begin{tabular}{|c|c|c|c|c|c|c|c|}
\hline \multicolumn{2}{|c|}{$G(s)=$} & $1+0$ & $\overline{+s^{2}}$ & & \multicolumn{2}{|c|}{$R=I, R^{\prime}=I$} & $=0.5[\mathrm{sec}]$ \\
\hline$Q, Q$ & & $i$ & 0 & 1 & 2 & 3 & 4 \\
\hline \multirow{4}{*}{$I$} & \multirow{2}{*}{ (a) } & $\bar{u}_{i}$ & 1.340 & 1.026 & 0.548 & -0.097 & 1.000 \\
\hline & & $\bar{y}_{i}$ & 0.000 & 0.154 & 0.507 & 0.856 & 1.000 \\
\hline & \multirow[b]{2}{*}{ (b) } & $\bar{u}_{i}^{\prime}$ & 1.597 & 1.778 & 0.181 & 1.000 & $\longrightarrow$ \\
\hline & & $\bar{y}_{i}^{\prime}$ & 0.115 & 0.222 & 0.107 & 0.000 & 1 \\
\hline \multirow{4}{*}{$30 I$} & \multirow{2}{*}{ (a) } & $\overline{\bar{u}_{i}}$ & 2.818 & -0.518 & -0.121 & 0.866 & 1.000 \\
\hline & & $\bar{y}_{i}$ & 0.000 & 0.323 & 0.800 & 0.982 & 1.000 \\
\hline & \multirow{2}{*}{ (b) } & $\bar{u}_{i}^{\prime}$ & 2.044 & 1.064 & 0.547 & 1.000 & 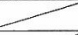 \\
\hline & & $\bar{y}_{i}^{\prime}$ & 0.115 & 0.170 & 0.059 & 0.000 & 7 \\
\hline \multirow{4}{*}{$100 I$} & \multirow{2}{*}{ (a) } & $\overline{\bar{u}_{i}}$ & 3.994 & -1.481 & -0.043 & 1.320 & 1.000 \\
\hline & & $\bar{y}_{i}$ & 0.000 & 0.458 & 0.990 & 1.042 & 1.000 \\
\hline & \multirow{2}{*}{ (b) } & $\bar{u}_{i}^{\prime}$ & 2.440 & 0.431 & 0.872 & 1.000 & 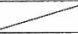 \\
\hline & & $\bar{y}_{i}^{\prime}$ & 0.115 & 0.125 & 0.017 & 0.000 & 1 \\
\hline \multirow{4}{*}{$1000 I$} & \multirow{3}{*}{ (a) } & $\overline{\bar{u}_{i}}$ & 6.237 & -5.895 & 3.124 & 0.637 & 1.000 \\
\hline & & $\bar{y}_{i}$ & 0.000 & 0.715 & 1.135 & 0.953 & 1.000 \\
\hline & & $\bar{u}_{i}^{\prime}$ & 2.857 & -0.234 & 1.213 & 1.000 & 7 \\
\hline & & $\bar{y}_{i}^{\prime}$ & 0.115 & 0.077 & -0.028 & 0.000 & 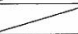 \\
\hline
\end{tabular}

表A2 制御対象とオーバパラメータモデルのパラメータ

\begin{tabular}{|c|c|c|c|c|c|c|c|c|}
\hline \multicolumn{3}{|c}{$G(s)=\frac{1}{1+0.4 s+s^{2}}$} & \multicolumn{3}{c}{$\begin{array}{l}\text { R=30I } \\
R=I\end{array}$} & \multicolumn{2}{c|}{$\begin{array}{l}Q^{\prime}=100 I \\
R^{\prime}=I\end{array}$} & \multicolumn{2}{c|}{$\begin{array}{c}\text { N=4, } \\
\theta=0.5[\mathrm{sec}]\end{array}$} \\
\hline$i$ & $a_{i}$ & $b_{i}$ & $\bar{a}_{i}$ & $\bar{b}_{i}$ & $\lambda_{i}$ & $\bar{a}_{i}^{\prime}$ & $\bar{b}_{i}^{\prime}$ & $\lambda_{i}^{\prime}$ \\
\hline 0 & & & & & 1.000 & & & 1.000 \\
\hline 1 & -1.597 & 0.115 & -1.056 & 0.115 & 0.541 & -1.440 & 0.115 & 0.157 \\
\hline 2 & 0.819 & 0.107 & 0.013 & 0.169 & 0.058 & 0.569 & 0.125 \\
\hline 3 & & & 0.350 & 0.065 & & 0.128 & 0.017 \\
\hline 4 & & & 0.048 & 0.006 & & & \\
\hline
\end{tabular}

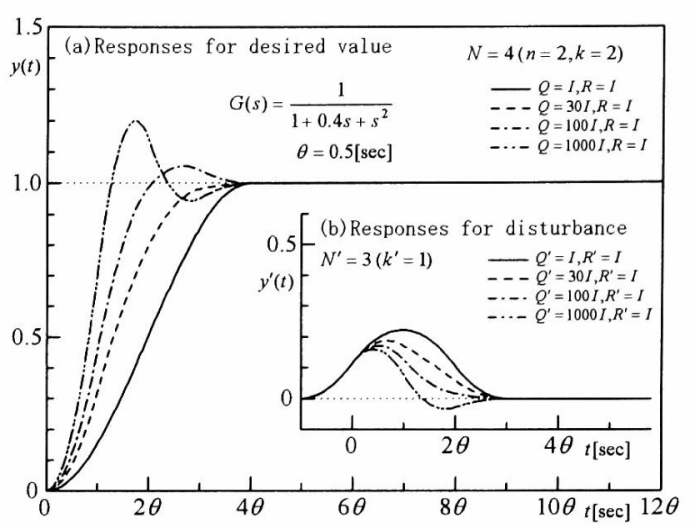

図A1 開ループ系の応答

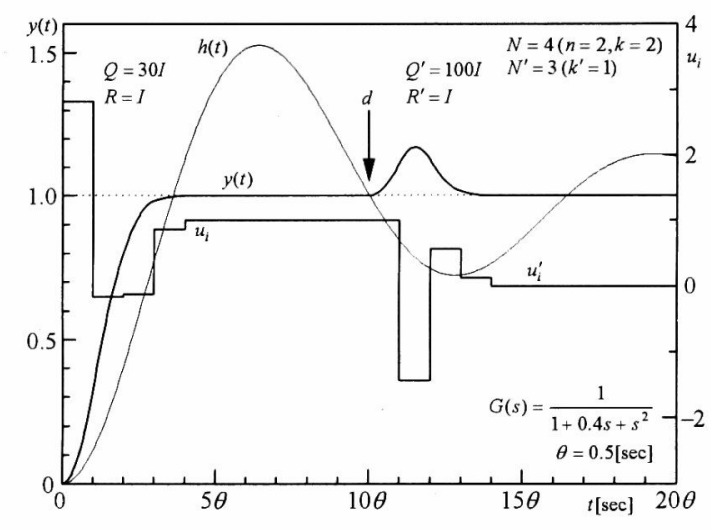

図A2 シミュレーション結果

上図はステップ状目標值変化に対する閉ループ采の応答 であり，100の時点で単位ステップ状の外乱を加えた場合 の応答も示してる。目標值に対しては図A1 (a)の破線の場 合における 4 段制御，外乱に対しては図A1（b)における一 点鎖線の場合の 3 段制御と同じ閉ループ応答が得られてお り，完全な 2 自由度最適有限整定制御が実現できている。

原田 賢一（学生員）1976年12月9日生。1999年3月広

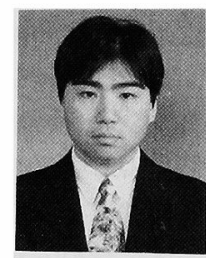
島工業大学電子工学科卒業。同年 4 月, 広 島市立大学大学院情報科学研究科情報機械 システム工学専攻入学, 現在に至る。

松岡 孝司 (学生員) 1977年2月20日生。1999年3月広

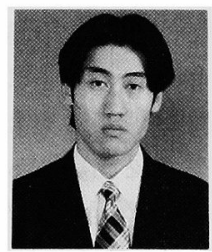
島工業大学電子工学科卒業。同年4月, (株) 協和エクシオに入社，現在に至る。

村田 弘志 （正員）電気学会論文誌 Vol. 119-C, No. 3 1999 参照。 